Research Article

Open Access

\title{
Impact of Ethylene Absorbents on Fruit Firmness and Quality of Nectarine (Prunus persica var. nectarina) Fruits during storage at Super Market Conditions
}

\author{
Smruthi Jayarajan and Ram Roshan Sharma ${ }^{*}$
}

Division of Food Science and Postharvest Technology, ICAR-Indian Agricultural Research Institute, New Delhi, India

\section{Article Info}

\section{*Corresponding author:}

Ram Roshan Sharma

Division of Food Science and Postharvest Technology

ICAR-Indian Agricultural Research Institute New Delhi, India

E-mail: rrs_fht@rediffmail.com

Received: September 20, 2018

Accepted: November 10, 2018

Published: November 16, 2018

Citation: Jayarajan S, Sharma RR. Impact of Ethylene Absorbents on Fruit Firmness and Quality of Nectarine (Prunus persica var. nectarina) Fruits during storage at super market conditions. Madridge J Food Technol. 2018; 3(2): 149-152.

doi: $10.18689 / \mathrm{mjft}-1000122$

Copyright: (c) 2018 The Author(s). This work is licensed under a Creative Commons Attribution 4.0 International License, which permits unrestricted use, distribution, and reproduction in any medium, provided the original work is properly cited.

Published by Madridge Publishers

\begin{abstract}
Nectarine (Prunus persica var. nectarina) is considered as a natural mutant of peach belonging to family Rosaceae. They have arisen from peach tree spontaneously as bud sport. Peach orchards are being replaced by nectarines because of its high demand among consumers. Nutritionally, nectarines are on par with the functional fruit, peach. The highly perishable nature of nectarine limits its shelf life to 3 to 4 days under ambient condition. But being a new crop, postharvest treatments to enhance its marketability is lacking. So as to tackle this problem, we conducted a study to enhance the marketability and shelf life of 'Silver Queen' nectarine by packing it with various ethylene absorbents. After harvesting at climacteric stage, nectarines were packed with different ethylene absorbent sachets such as $\mathrm{KMnO}_{4}$, Bioconservacion, $\mathrm{Al}_{2} \mathrm{O}_{3}$, silica gel and $\mathrm{KMnO}_{4}$ + silica gel and transported to IARI, New Delhi. Fruits were stored at supermarket condition $\left(18 \pm 2^{\circ} \mathrm{C}\right)$ and evaluated for various physical and biochemical parameters. Observations were recorded at fixed interval of 5 days. This study revealed that among the various ethylene absorbents used, $\mathrm{KMnO}_{4}$ sachets was found to be better in reducing ethylene evolution rate and respiration. It extended the shelf life up to 12 days at super market condition by maintaining better firmness (3.77N), low PLW (9.302\%) and higher ascorbic

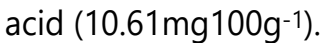

Keywords: Anthocyanin; Ascorbic acid; Ethylene absorbents; Nectarine.

\section{Introduction}

Nectarine (Prunus persica var nucipersica) is a smooth-skinned mutant of peach belonging to family Rosaceae; sub-family, Prunoidae and genus Prunus [1]. They have arisen from peach tree spontaneously as bud sport. The fuzzless nature of nectarine is attributed to the expression of a recessive allele [1]. The cultivation of this wonder crop is confined to warmer temperate regions of both the Northern and Southern hemispheres [2]. Nectarines bear attractive fruits of varying shades of red with varying colours of pulp ranging from red, yellow, or white pulp Fresh nectarines provide twice the vitamin $\mathrm{A}$, slightly more vitamin $\mathrm{C}$ and much more potassium and fiber than peaches and possess strong flavour and aroma [3]. Further, nectarines are juicy, delicious fruits having low calorific value (44 calories/100 g pulp) and have high antioxidant capacity which prevents oxidative stress by suppressing the ROS production in human plasma [4]. Hence the consumption of nectarines which is now considered as functional food is inevitable as it provides protection from chronic diseases.

The major constraint in nectarine handling is its limited shelf life due to its highly perishable nature. Ethylene evolution rate in nectarines invariably increases with the increase in storage period and temperature. Normally shelf life of nectarines is about 3-4 days at 
ambient conditions which can be extended up to 2-3 weeks under cold storage condition $\left(0-2^{\circ} \mathrm{C}, 85-90 \% \mathrm{RH}\right)$. Nectarines have limited shelf life due to its highly perishable nature. The key physiological and biochemical changes associated with ripening in climacteric fruits including nectarines such as fruit softening, change in peel colour, respiration and ethylene evolution rates, sugar, organic acid metabolism are regulated by the endogenous ethylene level in fruits [5-7]. Ethylene evolution rate in nectarines and peaches invariably increases with the increase in storage period and temperature [8]. As a result of increased activities of these enzymes and other biochemical attributes the shelf life of fruits reduced drastically. Apart from that, rough handling and poor storage conditions further enhances the perishability of fruits. Furthermore, very short shelf life of fruit is also attributed to the shorter time between the commercial ripening to the degradative senescence phase $[9,10]$. And hence there is a huge postharvest losses of about $25-30 \%$ during transportation and market chain. There are several postharvest management strategies to improve the postharvest shelf life of these perishable fruits by slowing down the metabolic activity, cold storage or lowering the storage temperature $[8,11]$, use of ethylene absorbents [12,13].

As India is developing country, such facilities are lacking, and if facilities are available, continuous supply of electricity is still a problem in several parts of the country. There are several postharvest interventions to enhance the storage life of fresh fruits but among them most convenient and economical method is the in-package use of ethylene absorbent sachets. Hence, we have attempted the use of $\mathrm{KMnO}_{4}$ based economically feasible ethylene absorbent sachets which were placed inside the packing boxes during the transportation of 'Silver Queen' nectarine.

\section{Materials and Methods}

The studies were conducted in the Division of Food Science \& Postharvest Technology, ICAR-IARI, New Delhi-110 012 during the fruiting season of 2016-17. Fruit of 'Silver Queen' variety was harvested at full maturity i.e., climacteric (ready-to-eat) on June15, 2016 from orchard of Regional Horticultural Research Station, Dr Y. S. Parmar University of Horticulture and Forestry, Bajaura, H.P. The orchard is located at $77^{\circ} 7^{\prime} 48^{\prime \prime} \mathrm{N}$ latitude, $31^{\circ} 58^{\prime} 56^{\prime \prime} \mathrm{E}$ longitude, and at an elevation of $1260 \mathrm{~m}$ above sea level. In this study, five ethylene absorbents were attempted, of which, four sachets containing $5 \mathrm{~g}$ each of $\mathrm{KMnO}_{4}$, Silica gel, Aluminium oxide, Silica gel + $\mathrm{KMnO}_{4}$, were prepared in the laboratory while a readymade ethylene removal sachet was supplied by BIOCONSERVACION S.A., Avinguda Diagonal, Barcelona, Spain free of cost for conducting the experiment.

After sorting, two ethylene absorbent sachets were placed each at the bottom, centre and at the top of packing box (CFB) containing five $\mathrm{kg}$ nectarine fruit, replicated thrice. The packed nectarines were transported to the Division of Food Science \& Postharvest Technology, IARI, New Delhi and stored at cold storage conditions $\left(18 \pm 2^{\circ} \mathrm{C}\right.$ and $\left.85-90 \% \mathrm{RH}\right)$ for twelve days for further observations at 4 days interval.
Determination of physiological loss in weight (PLW) and fruit firmness

All physical (PLW and fruit firmness) attributes of the tenrandomly selected 'Silver Queen' nectarine fruit were recorded at 5 intervals, replicated thrice. For the measurement of physiological loss in weight (PLW), fruit were weighed at regular intervals with the help of an electronic balance. The PLW was calculated by using the following formula and data were expressed in percentage.

PLW $(\%)=\frac{\text { Initial weight }- \text { Weight after known storage period } * 100}{\text { Initial weight }}$

Fruit firmness was determined using a texture analyzer (model: TA+Di, Stable micro systems, UK) using compression test, and expressed as $\mathrm{N}$ (Newton).

\section{Determination of anthocyanin content}

The biochemical attribute such as total anthocyanin content, was determined in ten-randomly selected nectarine fruit at 5 days interval, replicated thrice. The total monomeric anthocyanin content was determined by using the $\mathrm{pH}$-differential method [14] using two buffer systems- potassium chloride buffer, $\mathrm{pH} 1$ (0.025 M) and sodium acetate buffer, $\mathrm{pH} 4.5$ (0.4 M).

Absorbance $(A)=\left(A_{510 \mathrm{~nm}}-A_{700 \mathrm{~nm}}\right) \mathrm{pH} 1.0^{-}\left(A_{510 \mathrm{~nm}}-A_{700 \mathrm{~nm}}\right) \mathrm{pH} 4.5$ Monomeric anthocyanin content $\left(\mathrm{mgL}^{-1}\right)=\mathrm{A} \times \mathrm{MW} \times \mathrm{DF} \times 1000 /(\varepsilon \times 1)$

Where $\mathrm{A}=$ absorbance; $\mathrm{MW}=$ molecular weight (465.2); DF = dilution factor; $\varepsilon=$ molar absorptivity (795). The final concentration of anthocyanins was calculated based on total volume of extract and weight of sample.

\section{Determination of ascorbic acid}

The eating quality attributes, such as ascorbic acid content (AAC) were determined in ten-randomly selected nectarine fruit at weekly interval, replicated thrice. Ascorbic acid content of the fruit was determined using the method suggested by [15]. Ten $\mathrm{mL}$ of nectarine juice sample was taken, the volume of which was made up to $100 \mathrm{~mL}$ with $3 \% \mathrm{HPO}_{3}$ and it was then filtered [15]. The prepared fruit sample was taken in a conical flask and titrated against standardized 2,6 dichlorophenol indophenol dye, and expressed as mg $100 \mathrm{~g}^{-1}$ juice.

\section{Statistical design and analysis of data}

The data obtained from the experiments were analysed as per design and the results were compared from ANOVA by calculating the C.D. [16]. The data were analyzed using the SAS (Statistical Analysis System).

\section{Results and Discussion}

\section{Physiological loss in weight (\%)}

The results revealed that there was a significant influence of treatments, storage period and their interaction on PLW of 'Silver Queen' nectarine (Table 1). Physiological loss in weight $(P L W)$ is an important parameter as far as marketability is concerned. The freshness of fruit is of paramount importance while consumers select particular fruit. Hence in this study we could found that irrespective of storage period, treatments (ethylene absorbents) 
have shown significant effect on PLW. For instance, the PLW was lowest in $\mathrm{KMnO}_{4}$ (5.484\%) and highest in control fruits (7.643\%). The PLW increased with the increase in storage period, the lowest being on $4^{\text {th }}$ day of storage $(2.19 \%)$ and highest on $12^{\text {th }}$ day of storage (11.05\%). Interestingly, nectarine fruits placed in $\mathrm{KMnO}_{4}$ exhibited only $9.302 \%$ PLW on $12^{\text {th }}$ day of storage, which meets our international acceptance standards (Table 1).

Table 1. Effect of in-package use of ethylene absorbents on physiological loss in weight (\%) of 'Silver Queen' nectarine during storage under supermarket conditions.

\begin{tabular}{|c|c|c|c|c|}
\hline \multirow{2}{*}{$\begin{array}{l}\text { Ethylene } \\
\text { absorbent }\end{array}$} & \multicolumn{4}{|c|}{ Storage period (day) } \\
\hline & $4^{\text {th }}$ & $8^{\text {th }}$ & $12^{\text {th }}$ & Mean \\
\hline Control & 2.537 & 7.987 & 12.406 & 7.643 \\
\hline $\mathrm{KMnO}_{4}$ & 1.830 & 5.320 & 9.302 & 5.484 \\
\hline Silica gel & 1.960 & 5.865 & 10.115 & 5.980 \\
\hline $\mathrm{Al}_{2} \mathrm{O}_{3}$ & 2.250 & 6.842 & 11.898 & 6.997 \\
\hline $\mathrm{KMnO}_{4}+$ Silica gel & 2.168 & 5.900 & 10.000 & 6.148 \\
\hline Bioconservacion & 2.406 & 7.678 & 12.210 & 7.431 \\
\hline Mean & 2.192 & 6.599 & 11.051 & \\
\hline
\end{tabular}

The lower PLW in $\mathrm{KMnO}_{4}$ treated fruits may be due to higher ethylene oxidizing capacity and less moisture loss or transpiration rate than other absorbents. Similarly, higher PLW in control fruits may be due higher water loss by way of higher transpiration Ethylene absorbents are most effective in reducing physiological loss in weight and thereby increasing the postharvest life of fruits and vegetables. Fig fruits treated with $\mathrm{KMnO}_{4}$ extended the shelf life upto 10th day after storage by reducing the PLW [17].

\section{Fruit firmness (N)}

Our results revealed that ethylene absorbent treatments have influenced the firmness of 'Silver Queen' nectarines. Fruit firmness decreased considerably from 0 th day to $12^{\text {th }}$ day of storage. However, the rate of decline was higher and faster in the untreated fruits than those packed with different ethylene absorbents (Figure 1). Among different ethylene absorbents, the minimum firmness was recorded in untreated (control) fruits $(2.36 \mathrm{~N})$ and maximum in $\mathrm{KMnO}_{4}$ sachets $(3.77$ $\mathrm{N})$ at the end of storage period (Figure 1).

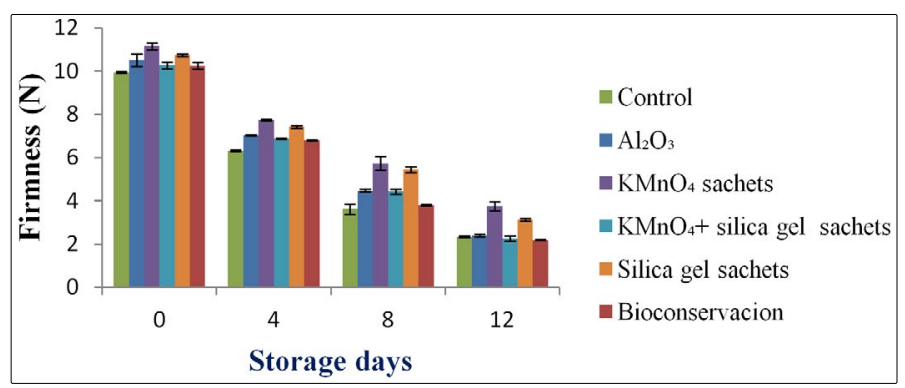

Figure 1. Influence of ethylene absorbents on fruit firmness of 'Silver Queen' nectarine under supermarket storage conditions

Firmness is one among those parameters by which consumers acceptability is evaluated. So to have a good marketability, fruits should be firm enough. The treatments have influenced the firmness of 'Silver Queen' nectarines. Among different ethylene absorbents, the minimum firmness was recorded in untreated (control) fruits $(1.36 \mathrm{~N})$ and maximum in $\mathrm{KMnO}_{4}(3.26 \mathrm{~N})$ at the end of storage period. Improvement in fruit firmness by the use of ethylene absorbents have also been reported in apple [12], grapes [18] and plum [7].

\section{Total anthocyanin content}

It is clearly evident from the table 2 that treatment, storage alone and in combination, have significantly influenced the anthocyanin content present in 'Silver Queen' nectarine. Regardless of storage, treatments have considerably influenced the anthocyanin content. The highest anthocyanin content was found in fruits being packed with silica gel (226.20) and $\mathrm{KMnO}_{4}$ (224.68 $\mathrm{mgkg}^{-1} \mathrm{FW}$ ) and lowest in fruits packed with Bioconservacion (184.04 mgkg-1 FW). The amount of anthocyanin in 'Silver Queen' nectarine significantly increased with increase in storage (Table 2). The lowest anthocyanin content was recorded on initial day (169.81 mgkg-1) and the highest on $12^{\text {th }}$ day of storage (204.63 $\left.\mathrm{mgkg}^{-1} \mathrm{FW}\right)$.

Table 2. Impact of in-package use of ethylene absorbents on anthocyanin content ( $\mathrm{mgkg}^{-1} \mathrm{FW}$ ) of 'Silver Queen' nectarine during storage under supermarket conditions.

\begin{tabular}{|l|c|c|c|c|c|}
\hline \multirow{2}{*}{ Ethylene absorbent } & \multicolumn{5}{|c|}{ Storage period (day) } \\
\cline { 2 - 6 } & 0th & 4th & 8th & 12th & Mean \\
\hline Control & 172.73 & 181.78 & 185.29 & 202.18 & 185.50 \\
\hline $\mathrm{KMnO}_{4}$ & 174.99 & 184.52 & 194.66 & 224.68 & 194.71 \\
\hline Silica gel & 167.24 & 177.30 & 188.42 & 226.20 & 187.67 \\
\hline $\mathrm{Al}_{2} \mathrm{O}_{3}$ & 163.54 & 174.18 & 179.83 & 187.54 & 176.27 \\
\hline $\mathrm{KMnO}_{4}+$ Silica gel & 179.58 & 196.61 & 208.12 & 211.63 & 198.98 \\
\hline Bioconservacion & 160.81 & 169.89 & 174.57 & 184.04 & 172.33 \\
\hline Mean & 169.81 & 180.71 & 188.48 & 204.63 & \\
\hline
\end{tabular}

LSD (0.05) for Treatment $(T)=1.83$; Storage period $(S)=1.49$ and Treatment $(T)$ $x$ Storage period $(S)=3.68$

Treatments, storage period and their combination have significantly influenced the biochemical attributes such as anthocyanin content, nectarines packed with various ethylene absorbent sachets. Increase in total anthocyanin content during storage may be due intensification of colour. Our study is in line with Sharma et al. [7], where they reported significantly higher levels of anthocyanin in 'Santa Rosa' plums when packed with ethylene absorbents.

\section{Ascorbic acid content}

The data shown in the table 3 revealed that treatment and storage alone and in combination showed a significant influence on ascorbic acid content of the 'Silver Queen' nectarine fruit. Irrespective of storage period, treatment has significantly influenced the ascorbic acid content of nectarine fruit (Table 3). Among the different in-package ethylene absorbents used, the maximum ascorbic acid was found in fruits packed with silica gel (10.88mg $100 \mathrm{~g}-1$ ) and the minimum in fruits packed without any ethylene absorbent $(9.43 \mathrm{mg} 100 \mathrm{~g}-1)$.

Table 3. Effect of ethylene absorbents on ascorbic acid (mg100g-1 pulp) of 'Silver Queen' nectarine fruit

\begin{tabular}{|l|c|c|c|c|c|}
\hline \multirow{2}{*}{ Ethylene absorbent } & \multicolumn{5}{|c|}{ Storage period (day) } \\
\cline { 2 - 6 } & $\mathbf{0}^{\text {th }}$ & $\mathbf{4}^{\text {th }}$ & 8th $^{\text {th }}$ & $\mathbf{1 2}^{\text {th }}$ & Mean \\
\hline Control & 9.83 & 9.59 & 9.27 & 9.04 & 9.43 \\
\hline $\mathrm{KMnO}_{4}$ & 11.14 & 10.97 & 10.82 & 10.61 & 10.88 \\
\hline Silica gel & 11.24 & 11.03 & 10.77 & 10.51 & 10.89 \\
\hline $\mathrm{Al}_{2} \mathrm{O}_{3}$ & 10.93 & 10.62 & 10.39 & 10.07 & 10.50 \\
\hline $\mathrm{KMnO}_{4}+$ Silica gel & 11.06 & 10.84 & 10.52 & 10.24 & 10.66 \\
\hline Bioconservacion & 9.88 & 9.52 & 9.32 & 9.10 & 9.46 \\
\hline Mean & 10.68 & 10.43 & 10.18 & 9.93 & \\
\hline MD $(0.05)$ & & &
\end{tabular}

LSD (0.05) for Treatment (T) $=0.03$; Storage period $(S)=0.029$ and Treatment $(\mathrm{T}) \times$ Storage period $(\mathrm{S})=.07$ 
Consumers prefer fruits with good eating qualities such as its sweetness, good flavor and other organoleptic properties like extend of acidity. In this study, we could found that ascorbic acid content in the 'Silver Queen' nectarine were significantly affected by different ethylene absorbents, storage period alone and the interaction of both. Thakur et al. [12] reported that 'Starking Delicious' apples showed slower decrease in TA during transportation when ethylene absorbents were placed in CFB boxes. The untreated nectarines have lower ascorbic acid content due to its utilization in several processes. 'Starking Delicious' apples with ethylene absorbents retained higher ascorbic acid as compared to untreated one [12].

\section{Conclusion}

The various ethylene absorbent sachets used in the study were very effective in controlling the PLW, firmness and significantly influenced the anthocyanin content. Hence, inpackage use of ethylene absorbents, especially $\mathrm{KMnO}_{4}$ sachets, can be recommended to enhance the shelf life of nectarine upto 12 days under supermarket condition without compromising the quality attributes.

\section{Acknowledgement}

We gratefully acknowledge Dr. Jayant, Associate Director, Regional Horticulture Research Station, Dr. Y. S. Parmar University of Horticulture and Forestry, Bajaura (H.P.) for providing fruit material of nectarine for conducting the present study.

\section{References}

1. Bal JS. Fruit growing. Kalyani Publishers. 2006.

2. Sharma RR, Krishna H. Fruit production: Minor fruits. Daya Publishing House. 2017.

3. Colaric M, Robert V, Stampar F, Hudina M. Evaluation of peach and nectarine fruit quality and correlations between sensory and chemical attributes. J Sci Food Agri. 2005; 85(15): 2611-2616. doi: 10.1002/jsfa.2316

4. Gil Ml, Tomas F, Betty BA, Pierce H, Kader AA. Antioxidant capacities, phenolic compounds, carotenoids, and vitamin $C$ contents of nectarine, peach, and plum cultivars from California. J Agri Food Chem. 2002; 50: 4976-4982.
5. Lelievre JM, Latche A, Jones $B$, Bouzayen $M$, Pech JC. Ethylene and fruit ripening. Physiol Plant. 1997; 101(4): 727-739. doi: 10.1111/j.1399-3054.1997. tb01057.x

6. Valero D, Serrano D. Postharvest Biology and Technology for Preserving Fruit Quality. CRC press, London, 2005.

7. Sharma S, Sharma RR, Pal RK, et al. Ethylene absorbents influence fruit firmness and activity of enzymes involved in fruit softening of Japanese plum (Prunus salicina L) cv. Santa Rosa. Fruits. 2007; 67(4): 257-266. doi: 10.1051/fruits/2012021

8. Aly MM, Agamy SZ, Biggs RH. Ethylene production and firmness of peach and nectarine fruits as related to storage. Proceedings of the Florida State Horticultural Society. 1981; 94: 291-294.

9. Egea MI, Martinez-Madrid MC, Sanchez-Bel P, Muricia MA. The influence of electron-beam ionization on ethylene metabolism and quality parameter in apricot (Prunus armeniaca L., cv. Builda). LWT- Food Science and Technology. 2007; 40(6): 1027-1035. doi: 10.1016/j.lwt.2006.06.005

10. Agar T, Polate A. Effect of different packing materials on the storage quality of some apricot varieties. Acta Hortic. 1993; 384: 625-631. doi: 10.17660/ActaHortic.1995.384.98

11. Sharma S, Sharma RR, Pal RK. Effect of ethylene absorbents on compression injury and quality of Santa Rosa Japanese plum (Prunus salicina L) during transportation. Indian J Agri Sci. 2012; 82(12): 223-226.

12. Thakur KS, Reddy VCM, Lal-Kaushal BB. Use of polyethylene box liners and ethylene absorbents for retention of quality of Starking Delicious apples during marketing. Acta Horti. 2005; 696: 463-465. doi: 10.17660/ ActaHortic.2005.696.82

13. Kaur AP, Singh K. Effect of ethylene absorbent on postharvest physiology of peach at ambient storage. Int J Agri Sci. 2011; 7(2): 378-381

14. Wrolstad RE, Durst RW, Lee J. Tracking color and pigment changes in anthocyanin products. Trends Food Sci Tech. 2005; 16(9): 423-428. doi: 10.1016/j.tifs.2005.03.019

15. Ranganna S. Handbook of Analysis and Quality Control for Fruits and Vegetable Products. 2nd edition. Tata McGraw-Hill Publishing Company Ltd; 1997.

16. Panse VG, Sukhatma PV. Statistical methods for agricultural workers. $3^{\text {rd }}$ edition. Indian Council of Agricultural Research; 1984.

17. Paramesha $\mathrm{D}$, Keerthishree $\mathrm{M}$, Prasad HP. Effect of $\mathrm{CaCl}_{2}$ and $\mathrm{KMnO}_{4}$ on shelf life of fig fruits. Int J Agri Sci. 2017; 9(18): 4170-4176.

18. Jang KI, Lee JH, Kim KY, Jeong HS. Quality of stored grape (Vitis labruscana) treated with ethylene absorbent and activated charcoal. Mono Korean Repub. 2006; 35(9): 1237-1244. doi: 10.3746/jkfn.2006.35.9.1237 